\title{
8
}

\section{Putting Artists and Guardians of Indigenous Works First: Towards a Restricted Scope of Freedom of Panorama in the Asian Pacific Region}

\author{
Jonathan Barrett
}

\section{Introduction}

'Freedom of panorama'2 permits use of certain copyright-protected works on public display; for example, anyone may publish and sell postcards of a public sculpture. ${ }^{3}$ The British heritage version of freedom of panorama, which is followed by many jurisdictions in the Asian Pacific region, ${ }^{4}$ applies

1 Copyright (C) 2018 Jonathan Barrett. Senior Lecturer, School of Accounting and Commercial Law, Victoria University of Wellington.

2 The term 'freedom of panorama' recently came into common usage in English. It appears to be derived from the Swiss German 'Panoramafreiheit', which itself has only been used since the 1990s, despite the exemption existing in German law for 170 years. See Mélanie Dulong de Rosnay and Pierre-Carl Langlais 'Public artworks and the freedom of panorama controversy: a case of Wikimedia influence' (2017) 6(1) Internet Policy Review.

3 Incidental copying of copyright works is not considered to be a feature of freedom of panorama. See Copyright Act 1994 (NZ), s 41.

4 Asian Pacific countries are those west of the International Date Line (IDL), as defined for the purposes of the Asian Pacific Copyright Association (APCA) in Brian Fitzgerald and Benedict Atkinson (eds) Copyright Future Copyright Freedom: Marking the 40 Year Anniversary of the Commencement of Australia's Copyright Act 1968 (Sydney University Press, Sydney, 2011) at 236. 
to buildings, sculptures and works of artistic craftsmanship on permanent display in a public place or premises open to the public. ${ }^{5}$ These objects may be copied in two dimensions, such as photographs. (Traditionally, this is known as reproducing 'the round' in 'the flat'. ${ }^{6}$ ) Owners of affected works may find themselves in competition in the market with others who are permitted to exploit those works, albeit in the flat. ${ }^{7}$ Furthermore, works on public display are commonly exposed to derogatory treatment. ${ }^{8}$

The impact of freedom of panorama on Indigenous ${ }^{9}$ artists is arguably most acute because their works may not be intended for commercial exploitation. ${ }^{10}$ Indeed, some works are sacred and should not be revealed to outsiders. ${ }^{11}$ An Indigenous artist whose work is exploited by outsiders may face serious community sanctions for failing in their guardianship

This definition mostly excludes British, European and United States copyright interests. However, any division of jurisdictions based on a construct such as the IDL will inevitably lead to arbitrary results. And so, while most of the United States' territories will be excluded, Guam lies west of the IDL. Likewise, French Polynesia will be mostly excluded but Wallis and Futuna lie west of the IDL, as does Francophone New Caledonia. Conversely, the Cook Islands and Niue, which are territories within the Realm of New Zealand, lie east of the IDL.

$5 \quad$ See Copyright, Patents and Designs Act 1988 (UK), s 62.

6 See JM Easton and WA Copinger The Law of Copyright in Works of Literature, Art, Architecture, Photography, Music and the Drama (5th ed, Stevens and Haynes, London, 1915) at 192.

7 In Radford $v$ Hallensteins Bros Ltd, New Zealand's leading case on freedom of panorama, the artist argued that a chain store's use of an image of his sculpture, by trivialising it, would deter serious collectors from buying miniature reproductions of the sculpture: see Radford $v$ Hallensteins Bros Ltd DC Auckland CIV-2005-004-3008, 6 June 2006; Radford v Hallensteins Bros Ltd HC Auckland CIV2006-404-4881, 22 February 2007; Radford v Hallensteins Bros Ltd [2009] DCR 907.

8 For example, Antony Gormley, STAY (2015/2016), a sculpture installed in Christchurch's Avon river, 'has been dressed in a high-viz vest and even an All Black jersey'. See Charlie Gates '\$800k Antony Gormley statue acting as a weed catcher' The Press (online ed, Christchurch, 7 June 2006). Moral rights, which protect authors' non-economic interests in their works, are generally unaffected by freedom of panorama. See Berne Convention for the Protection of Literary and Artistic Works 1161 UNTS 31 (opened for signature 9 September 1886, entered into force 5 December 1887), arts 6bis and 9 [Berne Convention]. However, in practice, artists are unlikely to assert their moral rights, even when the person in breach can be identified, because of the high costs of litigation in New Zealand.

9 The term 'Indigenous' is sufficiently problematic for the United Nations to avoid formulating a definition. Nevertheless, Indigeneity is reliably indicated by a group's continued expression of a distinct culture, despite colonisation or other domination. Minority groups within postcolonial societies, such as Māori within New Zealand, are likely to self-identify as Indigenous, but it is reasonable to assume that on the international stage, non-Europeans in ex-colonial countries, such as Samoans, have similar interests to minority groups in preserving their traditional expressions of culture. Consequently, this chapter adopts a broader than normal conception of Indigeneity.

10 See Bulun Bulun v R \& T Textiles [1998] ALR 157.

11 See Re Terry Yumbulul v Reserve Bank of Australia; Aboriginal Artists Agency Limited and Anthony Wallis [1991] FCA 448; 21 IPR 481. 
obligations. ${ }^{12}$ Indigenous peoples inhabit many countries in the Asian Pacific region, either in a minority or a majority; their artistic works may be adversely affected by excessively liberal freedom of panorama provisions.

The issues are exemplified by Ra Vincent's Wai-titi Landing (2005), ${ }^{13}$ which is a sculpture consisting of two pouwhenua (land-marking posts) and is situated near Parliament on Molesworth Street in Wellington, New Zealand. The Wellington Tenths Trust donated the sculpture to the city in the belief that it 'symbolises partnership between the city and local Te Atiawa/Taranaki people. ${ }^{14}$ Māori sculptures in the public space are typically gifted for particular purposes; they are treasures that Māori, through their carvers, ${ }^{15}$ have chosen to share with others. They are not commodities launched onto the market. Such artefacts may be open to public view but should not be game for commercial exploitation by anyone. Yet, several images of the sculpture are available for purchase on Alamy, an online stock photograph collection affiliated with Getty Images. ${ }^{16}$ Vincent is not identified as the sculptor. Conversely, Alamy ensures that its images cannot be downloaded without payment. ${ }^{17}$

This chapter argues that the Asian Pacific Copyright Code should adopt a restricted scope of freedom of panorama for the benefit of artists in general, but specifically for Indigenous artists and the guardians of their works. ${ }^{18}$ The chapter is structured as follows: first, relevant international treaty considerations are identified, in particular, art 9 of the Berne

12 See Miranda Forsyth 'Intellectual Property Laws in the South Pacific: Friend of Foe?' (2003)

7(1) J South Pac L www.paclii.org.

13 This example has been taken from Jonathan Barrett 'Time to Look Again? Copyright and Freedom of Panorama' (2017) 48(2) VUWLR 261 at 280.

14 See '11. Two pouwhenua, Wai-titi Landing', Wellington Sculptures www.sculptures.org.nz.

15 According to Māori tradition, pūmanawa (creative talent) 'comes to the individual through the parents and down through one's ancestry ... Whakapapa [genealogy] determines the distributions of talents': see Hirini Moko Mead Tikanga Mãori: Living by Mãori Values (Huia, Wellington, 2003) at 254-255.

16 Alamy www.alamy.com.

17 Alamy and Getty Images have been accused of wrongly offering copyright images for sale, and other sharp practices: see Ben Challis 'High Noon for Getty Images as a Photographer Bites Back' (2 August 2016) The 1709 Blog www.the1709blog.blogspot.co.nz.

18 In this chapter, 'guardian' refers to those people or groups who may or must protect particular works. In Te Reo Māori (the Māori language), they are denoted 'kaitiaki'. The trustee of a deceased artist's estate might play a comparable role in western culture. The types of artworks considered in this chapter are limited to things that currently attract copyright protection. Ancient cultural treasures in the public view are, for example, excluded. The Waitangi Tribunal comprehensively analysed Māori expectations about kaitiakitanga (guardianship) of their taonga (cultural treasures) and intellectual property rights. See Waitangi Tribunal Ko Aotearoa Tènei: A Report into Claims Concerning New Zealand Law and Policy Affecting Mäori Culture and Identity (Wai 262, 2011). 
Convention for the Protection of Literary and Artistic Works (Berne Convention) ${ }^{19}$ second, in order to more effectively engage with the 30 or so Asian Pacific jurisdictions, a taxonomy of freedom of panorama provisions is constructed; ${ }^{20}$ third, freedom of panorama provisions across the region are surveyed; fourth, focusing on the proportionality requirement of art 9(2) of the Berne Convention, ${ }^{21}$ a proposal for harmonised freedom of panorama across the Asian Pacific region is put forward.

\section{International Considerations}

This part of the chapter sketches the international agreements relevant to freedom of panorama.

\subsection{Berne Convention}

The Berne Convention, which is administered by the World Intellectual Property Organization (WIPO), ${ }^{22}$ establishes minimum copyright standards for its signatories, ${ }^{23}$ including an author's 'exclusive right of authorizing the reproduction of [qualifying] works, in any manner or form. ${ }^{24}$ Furthermore, non-signatory counties which are members of the World Trade Organization (WTO) must also comply with the key Berne provisions. ${ }^{25}$ Consequently, the only Asian Pacific countries which are not obliged to the follow art 9 of the Berne Convention are Marshall Islands, Nauru, Palau and Timor-Lesté. The Berne Convention implicitly permits, but does not mandate, freedom of panorama. Article 9(2) provides: $^{26}$

19 Berne Convention, above $\mathrm{n} 8$, art 9.

20 At the time of writing, I had not accessed the copyright legislation, if any existed, of the Marshall Islands or Timor Lesté.

21 Berne Convention, above n 8, art 9(2).

22 Berne Convention, above n 8; Asian Pacific countries that are not members of the World International Property Organization (WIPO) are: Marshall Islands, Federated States of Micronesia, Nauru, Palau, Solomon Islands and Timor-Lesté. See WIPO 'Member States' www.wipo.int.

23 Agreement on Trade-Related Aspects of Intellectual Property Rights 1869 UNTS 299 (adopted 15 April 1994, entered into force 1 January 1995) [TRIPS Agreement], art 9, provides: 'Members shall comply with Articles 1 through 21 of the Berne Convention (1971) and the Appendix thereto.'

24 Berne Convention, above n 8, art 9(1).

25 Asian Pacific countries that are neither members nor observers (future members) of the WTO are: Cook Islands, Kiribati, Marshall Islands, Federated States of Micronesia, Nauru, Niue, Palau, TimorLesté, and Tuvalu. See WTO 'Groups in the WTO: updated 7 April 2017’ www.wto.org. TRIPS, above n 23, art 9(1), only incorporates arts 1-21 (excluding art 6bis) of the Berne Convention, above n 8.

26 See also TRIPS, above n 23, art 13. 
It shall be a matter for legislation in the countries of the Union to permit the reproduction of such works in certain special cases, provided that such reproduction does not conflict with a normal exploitation of the work and does not unreasonably prejudice the legitimate interests of the author.

Article 9(2) establishes a three-step test to gauge the acceptability of an exception to the fundamental rights of copyright owners. ${ }^{27}$ Broadly, this requires a balancing of the interests of copyright owners and users, and is essentially a question of proportionality. ${ }^{28}$ In the Asian Pacific region, any consideration of the proportionality of freedom of panorama must take particular account of the interests of Indigenous artists.

\subsection{United Nations}

Various United Nations instruments are relevant to the protection of traditional knowledge, including the United Nations Educational, Scientific and Cultural Organization (UNESCO) Convention for the Protection of the World Cultural and Natural Heritage; ${ }^{29}$ UNESCO Convention for the Safeguarding of the Intangible Cultural Heritage; ${ }^{30}$ and the United Nations Declaration of the Rights of Indigenous Peoples 2007. ${ }^{31}$ These instruments are noted but will not be considered further in this chapter.

\subsection{Model Laws}

The imperative for Indigenous peoples' interests in their traditional knowledge to be balanced against western conceptions of individual copyright has been recognised in certain 'model laws', which are templates for domestic laws. ${ }^{32}$

27 Berne Convention, above n 8, art 9(2); For an analysis of the three-step test, see Sam Ricketson and Jane C Ginsburg International Copyright and Neighbouring Rights: the Berne Convention and Beyond Volume 1 (2nd ed, Centre for Commercial Law Studies, Queen Mary College, London, 2006) at [13.10]-[13.27].

28 See Christophe Geiger, Daniel Gervais and Martin Senftleben 'The Three-Step Test Revisited: How to Use the Test's Flexibility in National Copyright Law' (2014) 29(3) Am U Int L Rev 581 at 583. 29 Convention for the Protection of the World Cultural and Natural Heritage 1037 UNTS 151 (opened for signature 16 November 1972, entered into force 17 December 1975).

30 Convention for the Safeguarding of the Intangible Cultural Heritage 2368 UNTS 3 (opened for signature 17 October 2003, entered into force 20 April 2006).

31 United Nations Declaration on the Rights of Indigenous Peoples GA Res 61/295, A/Res/61/295 (2007).

32 WIPO Tunis Model Law on Copyright for Developing Countries (UNESCO, 1976); see Lida Ayoubi 'Copyright Harmonisation in the Asian Pacific Region: Weaving the Peoples Together?' in this volume. 


\subsubsection{Tunis Model Copyright Law}

The Tunis Model Copyright Law for Developing Countries (Tunis Model Law) recognises the economic importance of national folklore for less and least developed countries. ${ }^{33}$ (Indigenous people within more developed countries may be considered to be in a position analogous to citizens of developing countries.) The Commentary on the Tunis Model Law provides that 'in developing countries national folklore constitutes an appreciable part of the cultural heritage and is susceptible [to] economic exploitation, the fruits of which should not be denied to those countries'. ${ }^{34}$ The Commentary further notes: ${ }^{35}$

The object of [section 6 Works of national folklore] is to prevent any improper exploitation and to permit adequate protection of the cultural heritage known as folklore, which constitutes not only a potential for economic expansion, but also a cultural legacy intimately bound up with the individual character of each people. On these twofold grounds, works of folklore deserve protection, and the economic and moral rights in such works will be exercised, without limitation in time, by the competent national authority empowered to represent the people that originated them.

Section 7 of the Tunis Model Law permits: ${ }^{36}$

the reproduction of works of art and of architecture, in a film or in a television broadcast, and the communication to the public of the works so reproduced, if the said works are permanently located in a place where they can be viewed by the public.

\subsubsection{Pacific Model Law 2002}

In 2002, the Secretariat of the Pacific Community agreed on a Pacific Regional Framework for the Protection of Traditional Knowledge and Expressions of Culture, including the Pacific Model Law (Pacific Model Law). ${ }^{37}$ 'The Pacific Model Law is an IP-based sui generis

33 WIPO, above n 32, at 17.

34 At 17.

35 At 39.

36 Section 7.

37 Secretariat of the Pacific Community Regional Framework for the Protection of Traditional Knowledge and Expressions of Culture (Secretariat of the Pacific Community, 2002) www.forumsec.org [Pacific Model Law]. 
system ... It creates new IP, or IP-like, rights. ${ }^{38}$ Part 4 of the model law 'sets out the procedure for obtaining the prior and informed consent of the traditional owners to use their traditional knowledge or expressions of culture for a non-customary use (whether or not of a commercial nature)'. ${ }^{39}$ Specifically, s $15(1)$ provides: ${ }^{40}$

A prospective user of traditional knowledge or expression of culture for a non-customary use (whether or not of a commercial nature) may apply to the Cultural Authority to obtain the prior and informed consent of the traditional owners to use the traditional knowledge or expressions of culture.

Indigenous peoples' control over their expressions of culture is acutely relevant to freedom of panorama.

\section{Survey of Asian Pacific Provisions}

This part of the chapter establishes a taxonomy of regional freedom of panorama provisions. The purpose here is to aid effective engagement with the different provisions of the more than 30 Asian Pacific jurisdictions. Classification is for convenience purposes only and provides no more than a rough guide.

\subsection{British Heritage}

British heritage copyright law is prominent in the Asian Pacific region. Many Asian Pacific jurisdictions were once British colonies or protectorates of Australia or New Zealand, such as the Cook Islands, whose own copyright legislation has traditionally followed United Kingdom law. ${ }^{41}$ To reiterate, the basic British heritage copyright exemption for freedom of panorama applies to buildings, sculptures and works of artistic craftsmanship, which are on permanent display in a public place or premises open to the public. These objects may be copied in two-dimensional forms, such as

38 Secretariat of the Pacific Community Guidelines for Developing National Legislation for the Protection of Traditional Knowledge and Expressions of Culture Based on the Pacific Model Law 2002 (Secretariat of the Pacific Community, 2006) at 7.

39 Pacific Model Law, above n 37, at 7.

40 At 7 .

41 On New Zealand's following of United Kingdom copyright legislation, see Geoff McLay 'New Zealand and the Imperial copyright tradition' in Uma Suthersanen and Ysolde Gendreau (eds) A Shifting Empire: 100 Years of the Copyright Act 1911 (Edward Elgar, Cheltenham, 2013) at 30. 
photographs or television broadcasts. Australia, ${ }^{42}$ Nauru, ${ }^{43}$ Singapore ${ }^{44}$ and the Solomon Islands ${ }^{45}$ follow this model precisely. Variations are mostly determined by the vintage of the United Kingdom legislation followed - whether it is the $1911,{ }^{46} 1956^{47}$ or 1988 Act. $^{48}$ Fiji ${ }^{49}$ Hong Kong, ${ }^{50}$ New Zealand, ${ }^{51}$ Niue $^{52}$ and Tokelau ${ }^{53}$ all follow the 1988 legislation. Occasionally, British heritage copyright provisions appear to have been filtered through a locally dominant jurisdiction. For example, while

42 See Copyright Act 1968 (Cth), s 65.

43 English laws of general application in force on 31 January 1968 were adopted by Nauru, see Custom and Adopted Laws Act 1971 (Nauru), s 4.

44 See Copyright Act 1987 (Singapore), s 63.

45 See Copyright Act 1987 (Solomon Islands), s 7.

46 Copyright Act 1911 (UK), s 2(1) provided:

... the following acts shall not constitute the infringement of a copyright:-

(iii) The making or publishing of paintings, drawings, engravings, or photographs of a work of sculpture or artistic craftsmanship, if permanently situated in a public place, or building, or the making or publishing of paintings, drawings, engravings, or photographs (which are not in the nature of architectural drawings or plans) of any architectural work of art:

47 Copyright Act 1956 (UK), s 9 provided:

(3) The copyright in a work to which this subsection applies which is permanently situated in a public place, or in premises open to the public, is not infringed by the making of a painting, drawing, engraving or photograph of the work, or the inclusion of the work in a cinematograph film or in a television broadcast. This subsection applies to sculptures, and to such works of artistic craftsmanship as are mentioned in paragraph (c) of subsection (1) of section three of this Act.

(4) The copyright in a work of architecture is not infringed by the making of a painting, drawing, engraving or photograph of the work, or the inclusion of the work in a cinematograph film or in a television broadcast.

48 Copyright, Patents and Designs Act 1988 (UK), s 62 (as amended) provides:

(1) This section applies to-

(a) buildings, and

(b) sculptures, models for buildings and works of artistic craftsmanship, if permanently situated in a public place or in premises open to the public.

(2) The copyright in such a work is not infringed by-

(a) making a graphic work representing it,

(b) making a photograph or film of it, or

(c) making a broadcast of a visual image of it.

(3) Nor is the copyright infringed by the issue to the public of copies, or the communication to the public, of anything whose making was, by virtue of this section, not an infringement of the copyright.

49 See Copyright Act 1999 (Fiji), s 67(1).

50 Copyright Ordinance 2007 (Hong Kong), s 71.

51 See Copyright Act 1994 (NZ), s 73.

52 In terms of Niue Act 1966 (Niue), s 686, New Zealand copyright law generally applies in Niue. However, Niue may pass laws which amend the Niue version of the Act but not the New Zealand version.

53 New Zealand law applies in Tokelau: see New Zealand Law Rules 2004 (Tokelau), s 3. 
the New Zealand Copyright Act 1962 broadly followed the Copyright Act 1956 (UK), the former included murals in freedom of panorama, ${ }^{54}$ whereas the latter did not. ${ }^{55} \mathrm{New}$ Zealand exempted murals until its 1994 Copyright Act commenced, whereas the Cook Islands continued to include murals in its freedom of panorama exemption until 2013. ${ }^{56}$

Tonga has never been a colony of a western power, ${ }^{57}$ but has close ties to the United Kingdom and has adopted the English Common Law. Nevertheless, Tongan copyright law does not follow United Kingdom law, and permits 'the private reproduction of a published work in a single copy ... where the reproduction is made by a person exclusively for his own personal purposes' ${ }^{5}{ }^{5}$ However, this permitted use does not extend to reproducing, inter alia, 'a work of architecture in the form of building or other construction' or 'any work in cases where reproduction would conflict with a normal exploitation of the work or would otherwise unreasonably prejudice the legitimate interests of the author or other owner of the copyright'..$^{59}$

\subsection{United States Heritage}

The United States, whose law applies in the Commonwealth of the Northern Mariana Islands and Guam, limits freedom of panorama to architectural works in the public space.$^{60}$ However, in line with United States copyright law, ${ }^{61}$ Micronesian (FSM) legislation includes a fair use provision. ${ }^{62}$ The Philippines also has a general fair use provision. ${ }^{63}$ (The interaction between fair use and freedom of panorama lies beyond the scope of this chapter.)

\footnotetext{
54 See Copyright Act 1962 (NZ), s 20(5).

55 See Copyright Act 1956 (UK), s 9(3).

56 See Copyright Act 1962 (NZ), s 20(5), which applied in the Cook Islands in terms of the Cook Islands Act 1915 (NZ), s 627(1)). Section 627 remains on the New Zealand statute books despite the enactment of the Copyright Act 2013 (Cook Islands), which repeals the application of New Zealand copyright legislation in the Cook Islands.

57 See Sophie Foster and Sione Latukefu 'Tonga' (2016) Encyclopaedia Britannica www.britannica. com.

58 See Copyright Act 2002 (Tonga), s 8.

59 Section $8(2)$.

60 The United States provision only includes buildings in the freedom of panorama exemption: see 17 USC $\$ 120$ (a). For a discussion, see Bryce Clayton Newell 'Freedom of Panorama: A Comparative Look at International Restrictions on Public Photography' (2011) 44 Creighton L Rev 405.

61 On the United Sates influence over Micronesian (FSM) law, see 'Australia-Oceania: Micronesia, Federate States of' (15 June 2017) Central Intelligence Agency www.cia.gov.

62 See Annotated Code 2014 Title 3535 USC \$ 107.

63 See Intellectual Property Code, Republic Act No. 8293 (Philippines), s 185.
} 


\subsection{French Heritage}

France's ratification of the Stockholm Act 1967 of the Berne Convention included the following declaration: ${ }^{64}$

The Government of the French Republic ... declares that the said Convention shall be applicable to the territory of the French Republic in Europe, to the overseas territories of New Caledonia, French Polynesia, St. Pierre and Miquelon, Wallis and Futuna Islands and the French Southern and Antarctic Territories.

French law applies in its Polynesian territories, such as Wallis and Futuna. ${ }^{65}$ France has transferred certain legislative competence to New Caledonia with a view to future independence. ${ }^{66}$ Protection of Indigenous Kanak interests will be a principal motivation for developing laws differently from municipal French codes. ${ }^{67}$ Currently, New Caledonia's intellectual property code is a clone of the Code de la propriété intellectuelle 1992. ${ }^{68}$ Whether changes to the mother code will be adopted in New Caledonia is a matter of speculation.

Distinguished by its championing of authorial interests, French law has not traditionally recognised freedom of panorama. ${ }^{69}$ However, with effect from 7 October 2016, a limited freedom of panorama has been introduced by Loi pour une République Numérique, art $39,{ }^{70}$ which amends art L.122-5 of Code de la Propriété Intellectuelle, which limits an author's rights after divulgation, and is akin to fair dealing in British heritage copyright systems. And so, it is not breach of an author's rights for a natural person to reproduce or represent an architectural work or sculpture, which is permanently situated on a public road, provided this

64 WIPO 'Paris Notification No. 70 Paris Convention for the Protection of Industrial Property Ratification of the Stockholm Act by the French Republic' (notification, 12 May 1975) www.wipo.int. 65 Save for Wallis and Futuna, the territories which comprise French Polynesia lie east of the international date line. The laws of France generally apply in French Polynesia: see 'Australia-Oceania: French Polynesia' (26 June 2017) Central Intelligence Agency www.cia.gov.

66 See Loi du pays $n^{\circ} 2012-2$ du 20 janvier 2012 relative au transfert à la Nouvelle-Calédonie des compétences de l'Etat en matière de droit civil, de règles concernant l'état civil et de droit commercial (New Caledonia).

67 See Régis Lafargue 'The Unity of the Republic vs. Living together on the Same Land: New Caledonia from Colonization to Indigenousness: Law at the Center of a Major Culture Issue' (2014) 46(2) J Legal Pluralism 172.

68 Code de la Propriété Intellectuelle (France); see Loi n 92-597 du 1er juillet 1992 relative au code de la propriété intellectuelle (partie législative) (New Caledonia).

69 See Ashby Donald v France [2013] ECHR 287.

70 Loi pour une République Numérique (France), art 39; Code de la Propriété Intellectuelle (France), arts L.122-125. 
is not done commercially. ${ }^{71}$ The new rule will no doubt remove certain anomalies, ${ }^{72}$ but, as Marie-Andrée Weiss notes, the lack of a definition of commercial use (usage à caractère commercial) is likely to raise new problems. ${ }^{73}$ Would, for example, free blogs, which enjoy some support by advertising, be able to claim the exemption?

Despite its faults, the new French law represents an attempt to balance the interests of authors and others, as required by art 9(2) of the Berne Convention. ${ }^{74}$ There is nothing to suggest that British heritage systems have revisited the balance of their liberal freedom of panorama exemptions since the exemption was introduced in $1911 .^{75}$ The French law usefully indicates that a balanced freedom of panorama rule can give members of the public reproduction permission but also protect authors' interests from commercial exploitation.

\subsection{Other Civil Law Heritage}

Four civil-law jurisdictions - Japan, Korea, Taiwan and the Russian Federation - have broadly similar freedom of panorama exemptions, which are distinguished by their restrictions on non-authorial, commercial exploitation of public works.

71 In French: Les reproductions et représentations d'oeuvre architecturale et de sculptures, placée en permanence sur la voie publique, realisées par des personnes physiques, à l'exclusion de tout usage à caractère commercial.

72 For example, while the Eiffel Tower (which was built in 1889) is in the public domain, the tower's lighting was installed in 2003 and is copyright protected. This meant that, prior to 2016, a tourist could freely photograph the tower by day but not by night under the copyright-protected lighting: see 'IP and Business: Using Photographs of Copyrighted Works and Trademarks' WIPO Magazine (online ed, 2 April 2006) www.wipo.int.

73 Marie-Andrée Weiss 'The new, but narrow, French freedom of panorama exception' The 1709 Blog (18 October 2016) www.the1709blog.blogspot.co.nz.

74 Berne Convention, above n 8, art 9(2); Directive 2001/29/EC on the Harmonisation of Certain Aspects of Copyright and Related Rights in the Information Society [2001] OJ L 167/10 [InfoSoc] permits but does not mandate freedom of panorama. The Swedish Supreme Court's response to freedom of panorama and InfoSoc has been to prevent the not-for-profit WikiMedia from reproducing images of publicly displayed works. See Bildupphovsrätt $i$ Sverige (BUS) ek för $v$ Wikimedia Sverige, Ö 849-15, 4 April 2016. The case does not appear to be available in English. For a discussion of the case, see Nedim Malovic 'Swedish Supreme Court defines scope of freedom of panorama' (2016) 11(1) JIPLP 736.

75 See Copyright Act 1911 (UK), s 2(1)(iii). 


\subsubsection{Japan, Korea and Taiwan}

The Japanese exemption applies to all works of art, permanently located 'in open places accessible to the public, such as streets and parks, or at places easily seen by the public, such as the outer walls of buildings' ${ }^{76}$ However, sculptures may only be reproduced in three-dimensional form for personal use, and, generally, 'reproduction of an artistic work exclusively for the purpose of selling its copies and sale of such copies' is prohibited. ${ }^{77}$ This aversion to commercial exploitation of works in the public space is akin to the French approach, but direct French influence on Japanese copyright law in this area is not obvious. ${ }^{78}$ Korea's freedom of panorama provision is substantially similar to that of Japan. ${ }^{79}$ Taiwan's provision is also similar to that of Japan,$^{80}$ with the key distinguishing feature being a prohibition on commercial exploitation.

\subsubsection{Russian Federation}

Due to the unavailability of a reliable translation of the Civil Code, including all amendments, the scope of freedom of panorama in the Russian Federation is unclear. The text of the Code available through WIPO permits reproduction of works permanently located in a public place 'except for cases when the imaging of the work in this way is the main object of the reproduction, broadcast or cable transmission or when an image of the work is used for commercial purposes ${ }^{2}{ }^{81}$ WikiMedia indicates that freedom of panorama does not apply to public artworks but states 'exceptions for works of architecture, urban development, and garden and landscape design, which were added under consultation with Wikimedia Russia, have taken effect with the Civil Code amendments as of October $1,2014^{\prime}{ }^{82}$ It seems certain, however, that commercial exploitation of publicly displayed works is not permitted without the copyright owner's permission.

76 Copyright Law of Japan (Japan), art 45.

77 Article 46.

78 On the broad influence of French and German civil law on Japanese copyright law see Dennis $S$ Karjala and Keiji Sugiyama 'Fundamental Concepts in Japanese and American Copyright Law' (1988) 36(4) Am J Comp L 613 at 613.

79 See Copyright Act 2009 (Korea), s 35.

80 Copyright Act 2014 (Taiwan), art 58.

81 See Civil Code of the Russian Federation 1994 (as amended 2011) art 1276.

82 See 'Commons: Freedom of panorama' WikiMedia Commons (2017) commons.wikimedia.org. 


\subsection{China and Malaysia}

The freedom of panorama provisions of China and Malaysia defy easy categorisation or identification of provenance but may offer the broadest scope of freedom of panorama.

\subsubsection{China}

China's freedom of panorama provision reflects the language used in art 9(2) of the Berne Convention inasmuch as it implies a consideration of proportionality. Covering 'a work of art of art put up or displayed in outdoor public place', ${ }^{83}$ the provision is wider than the British heritage version since all artistic works are covered, and there is no explicit permanence of display requirement. Conversely, indoor works are not exempted. No restrictions appear to apply to the means of copying, such as recreating a sculpture in a three-dimensional reproduction. Furthermore, a commercial motive is expressly permitted. Despite the broad licence of the Chinese approach, in which regard we might speculate about the tradition of social 'ownership' of artworks in the public space, ${ }^{84}$ the moral right to be identified as the author is explicitly mentioned and other authorial rights must not be prejudiced. This latter requirement reflects the proportionality element of art 9(2) of the Berne Convention. ${ }^{85}$

\subsubsection{Malaysia}

Despite the common-law basis of its legal system, Malaysia does not follow British heritage copyright law with regard to freedom of panorama. Its broad exception provides that authorial rights do not extend to controlling the reproduction and distribution of copies of any artistic work permanently situated in a place where it can be viewed by the public'. ${ }^{86}$ This provision is notable because freedom of panorama is not restricted to three-dimensional artistic works in the public space.

83 See Copyright Law of the People's Republic of China 1999, art 22.

84 See, generally, William P Alfred To Steal a Book is an Elegant Offense: Intellectual Property Law

in Chinese Civilization (Stanford University Press, Redwood City (Cal), 1995).

85 Berne Convention, above n 8, art 9(2).

86 Copyright Act 1987(2) (MY), s 13. 


\subsection{Miscellaneous}

Any impact the Netherlands (in Indonesia), Portugal or Indonesia (in Timor-Lesté), the other ex-colonial powers in the region, ${ }^{87}$ may have had on their previous colonies' copyright law does not appear to have any lingering influence over freedom of panorama ${ }^{88}$ The relevant provisions of other Asian Pacific jurisdictions defy neat classification, and, indeed, vary considerably. The possibility of unreliable translation must also be taken into account.

The Cambodian exception is prima facie wide in its scope, provided moral rights are respected. Article 25 of the Law on Copyrights and Related Rights 2003 provides: ${ }^{89}$

If there is a clear indication of the author's name and the source of work, the following acts are not subjected to any prohibitions by the author ... The reproduction of graphic or plastic work which is situated in the public place...

However, this broad exception applies 'when this reproduction doesn't constitute the principle $[$ sic $]$ subject for subsequent reproduction'. ${ }^{90}$ Concerns for inaccurate translation noted, this qualifier may restrict the scope of the exception to incidental reproduction. If so, freedom of panorama, as contemplated in this chapter, is not a permitted use.

\subsection{Public Display Right-Only}

The Cook Islands, ${ }^{91}$ Indonesia, ${ }^{92}$ Palau, ${ }^{93}$ Papua New Guinea, ${ }^{94}$ Samoa ${ }^{95}$ and Vanuatu ${ }^{96}$ do not provide for freedom of panorama but establish a public display right. The Attorney-General of the Federated States of Micronesia has the power to regulate similarly. ${ }^{97}$ The typical provision allows public display of originals or copies of works, other than via films,

87 German colonisation of several Pacific islands, including Samoa, appears to have been too brief to have had any lasting influence on copyright law.

88 But see above n 63, on the Philippines fair use provision.

89 Law on Copyright and Related Rights 2003 (Cambodia), art 25.

90 Article 25.

91 Copyright Act 2013 (Cook Islands), s 23.

92 Law of the Republic of Indonesia 2014 about Copyright (Indonesia), art 15.

93 Consolidated Legislation Real and Personal Property Title 39 (Palau) 39 PNC \$ 821.

94 Copyright and Neighbouring Rights Act 2000 (Papua New Guinea), s 16.

95 See Copyright Act 1998 (Samoa), s 15.

96 See Copyright and Related Rights Act 2000 (Vanuatu), s 18.

97 See Annotated Code 2014 Title 35 Copyrights, Patents and Trademarks (Federated States of Micronesia), $\$ 107$. 
slides, television images or similar forms of communication, without the artist's permission. However, the work must have been divulged. The right to display works publicly is relevant to freedom of panorama because original copies of works entering the public space become susceptible to unauthorised reproduction or derogatory treatment. From a guardianship perspective, works may enter the public space which were never intended to leave the aegis of a particular community.

\subsection{No Explicit Exemption}

The copyright laws of Kiribati ${ }^{98}$ and Tuvalu ${ }^{99}$ are minimalist and do not mention either freedom of panorama or a public display right.

\subsection{Summary of Survey}

While noting the risk of oversimplifying disparate laws in the search for convenient commonalities, freedom of panorama provisions in the Asian Pacific region can be sorted into five loose categories - these may be termed: British heritage; United States heritage; French heritage; other civil law; and Chinese and Malaysian. The key features of these categories are summarised in tabular form below. For more detail, see the Appendix to this chapter.

Table 1: A comparison of the key features of freedom of panorama in the Asian Pacific region.

\begin{tabular}{|l|l|l|l|l|l|}
\hline & $\begin{array}{l}\text { British } \\
\text { heritage }\end{array}$ & US heritage & $\begin{array}{l}\text { French } \\
\text { heritage }\end{array}$ & $\begin{array}{l}\text { Other civil } \\
\text { law }\end{array}$ & $\begin{array}{l}\text { Chinese } \\
\text { (Malaysian) }\end{array}$ \\
\hline Works covered & $\begin{array}{l}\text { Three- } \\
\text { dimensional }\end{array}$ & $\begin{array}{l}\text { Architectural } \\
\text { works only } \\
\text { (and fair use) }\end{array}$ & $\begin{array}{l}\text { Three- } \\
\text { dimensional }\end{array}$ & All & All \\
\hline Period of display & Permanent & All times & Permanent & Permanent & All times \\
\hline $\begin{array}{l}\text { Scope of public } \\
\text { visibility }\end{array}$ & $\begin{array}{l}\text { Outdoor } \\
\text { and indoor }\end{array}$ & Outdoor & $\begin{array}{l}\text { Outdoor } \\
\text { (public way) }\end{array}$ & Outdoor & $\begin{array}{l}\text { Outdoor } \\
\text { (anywhere) }\end{array}$ \\
\hline $\begin{array}{l}\text { Permitted form } \\
\text { of copying }\end{array}$ & $\begin{array}{l}\text { Two- } \\
\text { dimensional }\end{array}$ & $\begin{array}{l}\text { Two- } \\
\text { dimensional }\end{array}$ & $\begin{array}{l}\text { Any } \\
\text { (unclear) }\end{array}$ & $\begin{array}{l}\text { Two- } \\
\text { dimensional }\end{array}$ & Any \\
\hline $\begin{array}{l}\text { Restrictions } \\
\text { on commercial } \\
\text { exploitation }\end{array}$ & None & None & $\begin{array}{l}\text { Permission } \\
\text { required }\end{array}$ & $\begin{array}{l}\text { Permission } \\
\text { required }\end{array}$ & None \\
\hline
\end{tabular}

Source: Author's summary.

98 See Laws of the Republic of Kiribati Revised Edition 1980 (Kiribati), Chapter 16 Copyright.

99 See Copyright Act 1916 (Tuvalu). 


\section{Evaluation and Recommendation}

The underpinning premise of this chapter is that the principle of proportionality established by art 9(2) of the Berne Convention ought to inform a freedom of panorama exemption. ${ }^{100}$ The Berne Convention does not prescribe precise provisions for Member States' copyright legislation but does establish minimum standards. A general exemption from the fundamental principle of authors' exclusive exploitation rights - indeed, the fundamental principle itself - was only included in the text of the Convention in 1967. ${ }^{101}$ This late inclusion partly accounts for the heterogeneity of freedom of panorama exemptions seen across the Asian Pacific region. But, analogous to European Union directives, which harmonise laws across diverse legal cultures but do not require uniformity in actual legislation, it is not far-fetched to propose restrictions on freedom of panorama in the Asian Pacific region. Harmonisation would not mean that countries which do not already recognise freedom of panorama would be required to do so, but countries which have unusually broad exemptions would be required to enact restrictions.

The principal interest-holders and the interests which should be appropriately balanced are:

1. Authors should be able to exploit their works in accordance with art 9(1) of the Berne Convention and to enforce their moral rights in terms of art 6bis. ${ }^{102}$

2. Cultural guardians should be able to protect their communal interests in cultural expressions in terms of UNESCO principles, the Pacific Model Law and so forth.

3. Not-for-profits, such as WikiMedia, should be able to disseminate images of copyright works in the public space to entertain and educate in terms of proportionate fair dealing rules or fair use principles, as contemplated in Berne Convention, art 9(2).

4. The general public should not be subjected to arbitrary rules about reproducing works in the public space and should normally be able to publish (for example, Facebook, Snapchat and so forth) images of public display works. For example, the two-dimensional and

100 Berne Convention, above n 8, art 9(2).

101 See Ricketson and Ginsburg, above n 27, at [11.06].

102 Berne Convention, above n 8, arts 9(1) and 6bis. 
three-dimensional distinction is arbitrary. Why should an amateur artist be able to sketch a public statue but not attempt to make a three-dimensional model?

5. Entrepreneurs may have an expectation of commercially exploiting works created by others but the justification for this is far from obvious. ${ }^{103}$

It is submitted that a fairer and more coherent balance may be struck between these competing interests than we currently find in freedom of panorama provisions in the Asian Pacific region. But, by drawing on the different provisions, we may craft a generic freedom of panorama provision suitable for regional harmonisation. The table below sets out the key features of the proposed provision, which aims to be better than current arrangements, if not perfect. ${ }^{104}$

Table 2: Proposal for freedom of panorama.

\begin{tabular}{|l|l|l|}
\hline Criterion & Scope & Justification \\
\hline Works covered & $\begin{array}{l}\text { All works in public } \\
\text { places }\end{array}$ & $\begin{array}{l}\text { Avoids arbitrary distinction between two- } \\
\text { and three-dimensional works }\end{array}$ \\
\hline Period of display & $\begin{array}{l}\text { Displayed at any } \\
\text { time }\end{array}$ & $\begin{array}{l}\text { Avoids arbitrary distinction between permanent } \\
\text { and public displays }\end{array}$ \\
\hline Scope of visibility & $\begin{array}{l}\text { Outdoor and } \\
\text { indoor }\end{array}$ & $\begin{array}{l}\text { Avoids arbitrary distinction between permanent } \\
\text { and public displays (museums and galleries } \\
\text { may restrict copying as a condition of entry) }\end{array}$ \\
\hline $\begin{array}{l}\text { Permitted form } \\
\text { of copying }\end{array}$ & Any & $\begin{array}{l}\text { Avoids arbitrary distinctions between two- } \\
\text { dimensional and three-dimensional copies }\end{array}$ \\
\hline $\begin{array}{l}\text { Not-for-profit } \\
\text { reproduction }\end{array}$ & $\begin{array}{l}\text { Permitted unless } \\
\text { owner objects }\end{array}$ & $\begin{array}{l}\text { Establishes a proportionate default rule which } \\
\text { favours not-for-profits and general public }\end{array}$ \\
\hline $\begin{array}{l}\text { Commercial } \\
\text { reproduction }\end{array}$ & $\begin{array}{l}\text { Prohibited unless } \\
\text { owner agrees }\end{array}$ & $\begin{array}{l}\text { Establishes a proportionate default rule which } \\
\text { favours artists and guardians }\end{array}$ \\
\hline
\end{tabular}

Source: Author's proposal.

In accordance with art 9(2) of the Berne Convention and art 13 of the Agreement on Trade-Related Intellectual Property Rights (TRIPS), the Asian Pacific Copyright Code para D proposes limitations and exceptions to copyright be confined to 'certain special cases' and should 'not conflict with a normal exploitation of the work and do not unreasonably

103 I have in mind here direct commercial exploitation, as seen in the examples discussed in the Introduction, rather than indirect commercial benefit; for example, when a blogger on public artworks attracts advertising revenue.

104 Practical issues of permission could, in particular, prove problematic. 
prejudice the legitimate interests of the rights owners' ${ }^{105}$ This approach would accommodate freedom of panorama arrangements, as varied as British and French heritage protections of the rights of the author, or new particular Asian versions. The legal heterogeneity of the Asian Pacific region prevents harmonisation based on common historical experience; rather, we need to look for commonalities across disparate cultures.

Everywhere, the majority of artists struggle to make a living. But, in the Asian Pacific region, consideration for the interests of Indigenous people must play a prominent role. In this context, empowering all artists (and guardians of their works) to prevent non-consensual exploitation of artworks in the public view is imperative. Conversely, users should not be subject to distinctions that appear irrational, such as between permanently and temporarily displayed artworks and permitted reproduction in 'the flat' but not in 'the round'.

\section{Conclusion}

Berne Union members negotiated the text of art 9(2) long after a variety of freedom of panorama exemptions had been enacted across different jurisdictions. Nevertheless, every WIPO and WTO member is obliged to ensure that its exemptions from copyright are restricted to 'certain special cases', do 'not conflict with a normal exploitation of the work', and do 'not unreasonably prejudice the legitimate interests of the author'. Broadly, this last requirement calls for a proportionate balancing of the interests of artists, including guardians of their works, and users. It seems unlikely that the broad, century-old British heritage exemption, which is followed in many Asian Pacific jurisdictions, has ever been subjected to a rigorous proportionality assessment. In contrast, French law has until recently refrained from recognising freedom of panorama. (That refusal is not, of course, subject to proportionality testing since Berne Union members are not required to provide exemptions to the fundamental author's reproduction right enshrined in art 9(1).)

In the Asian Pacific region, every country has either been the subject of colonialism or includes Indigenous communities who are dominated by an alien culture. It is trite that western conceptions of individualised intellectual property rights do not fit well with Indigenous conceptions

105 See Adrian Sterling 'Asian Pacific Copyright Code' in this volume. 
of traditional knowledge and cultural production and protection. In this context, the idea that an artwork, which an Indigenous community gifts to another community, might become fair game for commercial exploitation by anyone must be considered unacceptable. Freedom of panorama should not extend that far. Conversely, in a dominant legal-economic system, which is fundamentally informed by individual property rights, it is implausible to think that traditional arrangements might escape unscathed from collision with that hegemony. A compromise must be sought which does least harm.

A balanced freedom of panorama exemption should not only adequately protect artists' and guardians' interests, it should also remove the arbitrary binary oppositions for users between: 'in the flat' or 'in the round'; graphic works or sculptures; temporary or permanent displays; and twodimensional or three-dimensional reproduction. It is absurd to think that, say, a tourist taking a photograph of a mural that will be displayed in a public place for a finite period of time ought to be concerned about copyright infringement. (Galleries have the prerogative to decide whether artworks may or may not be photographed, ${ }^{106}$ and increasingly in public galleries, prohibition is the exception.) It seems perfectly reasonable that a tourist in Wellington, who sees Wai-titi Landing, should think they are entitled to take a 'selfie' in front of it and post that image on Facebook, ${ }^{107}$ just as much as they might include an image of the sculpture incidentally in a panning shot of the Parliamentary precinct. But a director of a fashion shoot who wishes to use the sculpture as a principal feature should reasonably expect the need to obtain permission, as should anyone who seeks a direct financial benefit from reproducing images of the sculpture.

Drawing on the best elements of freedom of panorama exemptions across the region, but excluding the least desirable features, this chapter proposes the following for the Asian Pacific Copyright Code: no distinction should be drawn between two-dimensional and three-dimensional works or between permanently and temporarily displayed works or whether they are displayed out of doors or indoors; no distinction should be drawn between two-dimensional and three-dimensional reproduction; however, non-commercial and commercial exploitation should be distinguished.

106 See Simon Stokes Art and Copyright (2nd ed, Hart Publishing, Oxford, 2012) at 67, n 160.

107 On possible Indigenous objections to this approach, see S Corbett and M Boddington 'Copyright Law and the Digitisation of Cultural Heritage' (Centre for Accounting, Governance \& Taxation Research, Working Paper Series, WP No. 77, September 2011). 
As a compromise, it is proposed that non-commercial reproduction should be permitted as a default; whereas commercial reproduction should only be allowed with permission. In either case, artists, owners or guardians would be able to prevent offensive reproduction.

\section{Appendix: Summary of Asian Pacific Freedom of Panorama Provisions}

\begin{tabular}{|c|c|}
\hline Country Statute & Summary of freedom of panorama provision \\
\hline \multicolumn{2}{|c|}{ British heritage copyright schemes } \\
\hline \multicolumn{2}{|l|}{ Australia } \\
\hline $\begin{array}{l}\text { Copyright Act } \\
1968, \text { s } 65 \\
\text { Compare: } \\
\text { Copyright Act } \\
1956 \text { (UK) }\end{array}$ & $\begin{array}{l}\text { (1) This section applies to sculptures and to works of artistic } \\
\text { craftsmanship of the kind referred to in paragraph (c) of the definition } \\
\text { of artistic work in section } 10 \text {. } \\
\text { (2) The copyright in a work to which this section applies that is } \\
\text { situated, otherwise than temporarily, in a public place, or in premises } \\
\text { open to the public, is not infringed by the making of a painting, } \\
\text { drawing, engraving or photograph of the work or by the inclusion } \\
\text { of the work in a cinematograph film or in a television broadcast. }\end{array}$ \\
\hline \multicolumn{2}{|l|}{ Fiji } \\
\hline \begin{tabular}{l|} 
Copyright Act \\
1999, s 67(1) \\
Compare: \\
Copyright Act \\
1956 (UK); and \\
Copyright Act \\
1962 (NZ)
\end{tabular} & $\begin{array}{l}\text { This section applies to- } \\
\text { (a) buildings; and } \\
\text { (b) works (being sculptures, models for buildings, or works of } \\
\text { artistic craftsmanship) that are permanently situated in a public } \\
\text { place or in premises open to the public. } \\
\text { (2) Copyright in a work to which this section applies is not infringed by- } \\
\text { (a) copying the work by making a graphic work representing it; } \\
\text { (b) copying the work by making a photograph or audiovisual work } \\
\text { of it; or } \\
\text { (c) broadcasting, or including in a cable programme, a visual } \\
\text { image of the work. } \\
\text { (3) Copyright is not infringed by the issue to the public of copies, } \\
\text { or the broadcasting or communication to the public or inclusion in } \\
\text { a cable programme, of anything the making of which was, under } \\
\text { this section, not an infringement of copyright. }\end{array}$ \\
\hline \multicolumn{2}{|l|}{ Hong Kong } \\
\hline $\begin{array}{l}\text { Copyright } \\
\text { Ordinance } \\
2007, \text { s } 71 \\
\text { Compare } \\
\text { Copyright, } \\
\text { Patents and } \\
\text { Designs Act } \\
1988 \text { (UK) }\end{array}$ & $\begin{array}{l}\text { (1) This section applies to- } \\
\text { (a) buildings; and } \\
\text { (b) sculptures, models for buildings and works of artistic } \\
\text { craftsmanship, if permanently situated in a public place } \\
\text { or in premises open to the public. } \\
\text { (2) The copyright in such a work is not infringed by- } \\
\text { (a) making a graphic work representing it; } \\
\text { (b) making a photograph or film of it; or } \\
\text { (c) broadcasting or including in a cable programme service } \\
\text { a visual image of it ... }\end{array}$ \\
\hline
\end{tabular}




\begin{tabular}{|c|c|}
\hline Country Statute & Summary of freedom of panorama provision \\
\hline \multicolumn{2}{|l|}{ Nauru } \\
\hline $\begin{array}{l}\text { Custom and } \\
\text { Adopted Laws } \\
\text { Act } 1971 \text {, s } 4 \\
\text { Compare: } \\
\text { Copyright Act } \\
1956 \text { (UK) } \\
\end{array}$ & $\begin{array}{l}\text { The Copyright Law of England applies in Nauru because, according to } \\
\text { the Custom and Adopted Laws Act } 1971 \text { of Nauru, the common law } \\
\text { and statutes of general application, which were in force in England on } \\
31 \text { January 1968, are adopted as laws of Nauru. }\end{array}$ \\
\hline \multicolumn{2}{|l|}{ New Zealand } \\
\hline $\begin{array}{l}\text { Copyright Act } \\
\text { 1994, s } 73 \\
\text { Compare: } \\
\text { Copyright Act } \\
1988 \text { (UK) }\end{array}$ & $\begin{array}{l}\text { This section applies to the following works- } \\
\text { (a) buildings: } \\
\text { (b) works (being sculptures, models for buildings, or works of } \\
\text { artistic craftsmanship) that are permanently situated in a public } \\
\text { place or in premises open to the public. } \\
\text { (2) Copyright in a work to which this section applies is not infringed by- } \\
\text { (a) copying the work by making a graphic work representing it; } \\
\text { or (b) copying the work by making a photograph or film of it; } \\
\text { or (c) communicating to the public a visual image of the work. } \\
\text { (3) Copyright is not infringed by the issue to the public of copies, } \\
\text { or the communication to the public, of anything the making of which } \\
\text { was, under this section, not an infringement of copyright. }\end{array}$ \\
\hline \multicolumn{2}{|l|}{ Niue } \\
\hline $\begin{array}{l}\text { Niue Act 1966, } \\
\text { s } 686\end{array}$ & $\begin{array}{l}\text { The Copyright Act } 1994 \text { shall be in force in Niue in the same manner } \\
\text { in all respects as if Niue were for all purposes part of New Zealand, } \\
\text { and the term 'New Zealand' as used in that Act shall, both in New } \\
\text { Zealand and in Niue, be read as including Niue accordingly. } \\
\text { See also Tāoga Niue Act } 2012 \text {. }\end{array}$ \\
\hline \multicolumn{2}{|l|}{ Singapore } \\
\hline $\begin{array}{l}\text { Copyright Act } \\
1987, \text { s } 63 \\
\text { Compare: } \\
\text { Copyright Act } \\
1968 \text { (Cth); and } \\
\text { Copyright Act } \\
1956 \text { (UK) }\end{array}$ & $\begin{array}{l}\text { (1) This section shall apply to sculptures and to works of artistic } \\
\text { craftsmanship of the kind referred to in paragraph (c) of the definition } \\
\text { of 'artistic work' in section } 7 \text {. } \\
\text { (2) The copyright in a work to which this section applies that is } \\
\text { situated, otherwise than temporarily, in a public place, or in premises } \\
\text { open to the public, is not infringed by the making of a painting, } \\
\text { drawing, engraving or photograph of the work or by the inclusion } \\
\text { of the work in a cinematograph film or in a television broadcast. }\end{array}$ \\
\hline \multicolumn{2}{|l|}{ Solomon Islands } \\
\hline $\begin{array}{l}\text { Copyright Act } \\
1987, \text { s } 7 \\
\text { Compare: } \\
\text { Copyright Act } \\
1968 \text { (Cth) }\end{array}$ & $\begin{array}{l}\text { (7) The copyright in- } \\
\text { (a) any sculpture; or } \\
\text { (b) any work of artistic craftsmanship of the kind described in the } \\
\text { definition of 'artistic work' in subsection (1) of section 2, which } \\
\text { is permanently situated in a public place, or in premises open to } \\
\text { the public, is not infringed by the making of a painting, drawing, } \\
\text { engraving or photograph of the work, or the inclusion of the work } \\
\text { in a cinematograph film or in a television broadcast. } \\
\text { (8) The copyright in a work of architecture is not infringed by the } \\
\text { making of a painting, drawing, engraving or photograph of the work, } \\
\text { or the inclusion of the work in a cinematograph film or in a television } \\
\text { broadcast. }\end{array}$ \\
\hline
\end{tabular}




\begin{tabular}{|c|c|}
\hline Country Statute & Summary of freedom of panorama provision \\
\hline \multicolumn{2}{|l|}{ Tokelau } \\
\hline $\begin{array}{l}\text { Application of } \\
\text { New Zealand } \\
\text { Law Rules } \\
2004, \text { s } 3 \\
\end{array}$ & New Zealand law applies to intellectual property. \\
\hline \multicolumn{2}{|l|}{ Tonga } \\
\hline $\begin{array}{l}\text { Copyright Act } \\
\text { 2002, s } 11\end{array}$ & $\begin{array}{l}\text { (1) ... the private reproduction of a published work in a single copy } \\
\text { shall be permitted without the authorisation of the author or owner of } \\
\text { copyright, where the reproduction is made by a person exclusively for } \\
\text { his own personal purposes. } \\
\text { (2) The permission under subsection (1) shall not extend to } \\
\text { reproduction- } \\
\text { (a) of a work of architecture in the form of building or other } \\
\text { construction ... } \\
\text { (e) of any work in cases where reproduction would conflict with } \\
\text { a normal exploitation of the work or would otherwise unreasonably } \\
\text { prejudice the legitimate interests of the author or other owner } \\
\text { of the copyright. }\end{array}$ \\
\hline \multicolumn{2}{|c|}{ Specific national provisions } \\
\hline \multicolumn{2}{|l|}{ Cambodia } \\
\hline $\begin{array}{l}\text { Law on } \\
\text { Copyrights and } \\
\text { Related Rights } \\
2003 \text {, art } 25\end{array}$ & $\begin{array}{l}\text { If there is a clear indication of the author's name and the source of } \\
\text { work, the following acts are not subjected to any prohibitions by the } \\
\text { author ... } \\
\text { The reproduction of graphic or plastic work which is situated in the } \\
\text { public place, when this reproduction doesn't constitute the principle } \\
\text { [sic] subject for subsequent reproduction. }\end{array}$ \\
\hline \multicolumn{2}{|l|}{ China } \\
\hline $\begin{array}{l}\text { Copyright Law } \\
\text { of the People's } \\
\text { Republic of } \\
\text { China 1990, } \\
\text { art } 22\end{array}$ & $\begin{array}{l}\text { In the following cases, a work may be used without permission } \\
\text { from, and without payment of remuneration to, the copyright owner, } \\
\text { provided that the name of the author and the title of the work are } \\
\text { mentioned and the other rights enjoyed by the copyright owner in } \\
\text { accordance with this Law are not prejudiced ... } \\
\text { (10) copying, drawing, photographing or video-recording of a work } \\
\text { of art put up or displayed in an outdoor public place. }\end{array}$ \\
\hline
\end{tabular}




\begin{tabular}{|c|c|}
\hline Country Statute & Summary of freedom of panorama provision \\
\hline \multicolumn{2}{|l|}{ Japan } \\
\hline $\begin{array}{l}\text { Copyright } \\
\text { Law of Japan, } \\
\text { arts } 45 \text { and } 46\end{array}$ & $\begin{array}{l}\text { Art 45. (1) The original of an artistic work or a photographic work may } \\
\text { be publicly exhibited by its owner or with his authorization. } \\
\text { (2) The provision of the preceding paragraph shall not apply with } \\
\text { respect to the permanent location of the original of an artistic work in } \\
\text { open places accessible to the public, such as streets and parks, or at } \\
\text { places easily seen by the public, such as the outer walls of buildings. } \\
\text { Art } 46 \text {. It shall be permissible to exploit artistic works permanently } \\
\text { located in such open places as mentioned in paragraph (2) of the } \\
\text { preceding Article and architectural works by any means not falling } \\
\text { within any of the following items: } \\
\text { (i) multiplication of a sculpture and offering it to the public } \\
\text { by transfer of ownership of its copies; } \\
\text { (ii) imitative reproduction of an architectural work and offering } \\
\text { it to the public by transfer of ownership of its copies; } \\
\text { (iii) reproduction of a work for the purpose of locating it } \\
\text { permanently in such open places as mentioned in paragraph (2) } \\
\text { of the preceding Article; } \\
\text { (iv) reproduction of an artistic work exclusively for the purpose } \\
\text { of selling its copies and sale of such copies. }\end{array}$ \\
\hline \multicolumn{2}{|l|}{ Korea } \\
\hline $\begin{array}{l}\text { Copyright Act } \\
2009 \text {, s } 35\end{array}$ & $\begin{array}{l}\text { (1) The owner of the original of a work of art, etc. or a person who has } \\
\text { obtained the owner's authorization, may exhibit the work in its original } \\
\text { form: provided that this provision shall not apply if the work of art is } \\
\text { to be permanently exhibited in a street or park, on the exterior of a } \\
\text { building, or other places open to the public. } \\
\text { (2) Works of art, etc. exhibited at all times at an open place as referred } \\
\text { to in the proviso of Paragraph (1) may be reproduced and used by any } \\
\text { means, except those falling under any of the following cases: } \\
\text { 1. Where a building is reproduced in another building; } \\
\text { 2. Where a sculpture or a painting is reproduced in another } \\
\text { sculpture or a painting; } \\
\text { 3. Where the reproduction is made in order to exhibit permanently } \\
\text { at an open place, as prescribed under the proviso of Paragraph } \\
\text { (1); and } \\
\text { 4. Where the reproduction is made for the purpose of selling } \\
\text { its copies. }\end{array}$ \\
\hline \multicolumn{2}{|c|}{ Russian Federation } \\
\hline $\begin{array}{l}\text { Civil Code of } \\
\text { the Russian } \\
\text { Federation } 1994 \\
\text { (as amended } \\
\text { 2011) art } 1276\end{array}$ & $\begin{array}{l}\text { A photographic work, an architectural work or an artistic work that is } \\
\text { permanently located in a place open to the public may be reproduced, } \\
\text { broadcast or transmitted by cable without the consent of the author } \\
\text { or other right holder and without paying out a fee, except for cases } \\
\text { when the imaging of the work in this way is the main object of the } \\
\text { reproduction, broadcast or cable transmission or when an image } \\
\text { of the work is used for commercial purposes. }\end{array}$ \\
\hline
\end{tabular}




\begin{tabular}{|c|c|}
\hline Country Statute & Summary of freedom of panorama provision \\
\hline \multicolumn{2}{|l|}{ Taiwan } \\
\hline $\begin{array}{l}\text { Copyright Act } \\
2014 \text {, art } 58\end{array}$ & $\begin{array}{l}\text { Artistic works or architectural works displayed on a long-term basis } \\
\text { on streets, in parks, on outside walls of buildings, or other outdoor } \\
\text { locales open to the public, may be exploited by any means except } \\
\text { under the following circumstances: } \\
\text { 1. Reproduction of a building by construction of another building. } \\
\text { 2. Reproduction of a work of sculpture by production of another } \\
\text { sculpture. } \\
\text { 3. Reproduction for the purpose of long-term public display } \\
\text { in locales specified in this article. } \\
\text { 4. Reproduction of artistic works solely for the purpose of selling } \\
\text { copies. }\end{array}$ \\
\hline \multicolumn{2}{|l|}{ Thailand } \\
\hline $\begin{array}{l}\text { Copyright Act } \\
\text { 1994, s } 37\end{array}$ & $\begin{array}{l}\text { A drawing, painting, construction, engraving, molding, carving, } \\
\text { lithography, photograph, film, video broadcast or any similar use of an } \\
\text { artistic work, except for an architectural work, which is openly located } \\
\text { in a public place shall not be deemed an infringement of copyright in } \\
\text { the artistic work. } \\
\text { 38. A drawing, painting, engraving, molding, carving, lithography, } \\
\text { photograph, film or video broadcast of an architectural work shall not } \\
\text { be deemed an infringement of copyright in the architectural work. }\end{array}$ \\
\hline \multicolumn{2}{|l|}{ Malaysia } \\
\hline $\begin{array}{l}\text { Copyright Act } \\
1987(2), \text { s } 13\end{array}$ & $\begin{array}{l}\ldots \text { the right of control ... does not include the right to control ... } \\
\text { (d) the reproduction and distribution of copies of any artistic work } \\
\text { permanently situated in a place where it can be viewed by the public. }\end{array}$ \\
\hline \multicolumn{2}{|l|}{ Vietnam } \\
\hline $\begin{array}{l}\text { Law on } \\
\text { Intellectual } \\
\text { Property } \\
\text { (No. 50/2005/ } \\
\text { QH11), art } 25\end{array}$ & $\begin{array}{l}\text { Cases of use of published works where permission or payment } \\
\text { of royalties and/or remunerations is not required include ... } \\
\text { h/ Photographing or televising of plastic art, architectural, } \\
\text { photographic, applied-art works displayed at public places } \\
\text { for purpose of presenting images of such works. }\end{array}$ \\
\hline \multicolumn{2}{|c|}{ Public display provisions only } \\
\hline \multicolumn{2}{|l|}{ Cook Islands } \\
\hline $\begin{array}{l}\text { Copyright Act } \\
2013 \text {, s } 23\end{array}$ & $\begin{array}{l}\text { (1) A person does not infringe copyright in a work if the person publicly } \\
\text { displays a work or copies of the work- } \\
\text { (a) for the purposes of promoting the work, testing the work, } \\
\text { or training users of the work; and } \\
\text { (b) without the authorisation of the owner of the copyright } \\
\text { in the work. }\end{array}$ \\
\hline
\end{tabular}




\begin{tabular}{|c|c|}
\hline Country Statute & Summary of freedom of panorama provision \\
\hline \multicolumn{2}{|c|}{ Federated States of Micronesia } \\
\hline \begin{tabular}{l|} 
Annotated \\
Code 2014 Title \\
35 Copyrights, \\
Patents and \\
Trademarks, \\
$\S 107$
\end{tabular} & $\begin{array}{l}\text { § 107. Limitation on exclusive rights-Fair use. } \\
\text { Notwithstanding the provisions of section } 106 \text { of this chapter, the } \\
\text { fair use of a copyrighted work, including such use by reproduction } \\
\text { in copies or phonorecords or by any other means specified by that } \\
\text { section, for purposes such as criticism, comment, news reporting, } \\
\text { teaching (including multiple copies for classroom use), scholarship, } \\
\text { or research, is not an infringement of copyright. In determining } \\
\text { whether the use made of a work in any particular case is a fair use } \\
\text { the factors to be considered shall include: } \\
\text { (1) the purpose and character of the use, including whether such } \\
\text { use is of a commercial nature or is for nonprofit educational } \\
\text { purposes; } \\
\text { (2) the nature of the copyrighted work; } \\
\text { (3) the amount and substantiality of the portion used in relation } \\
\text { to the copyrighted work as a whole; and } \\
\text { (4) the effect of the use upon the potential market for or value } \\
\text { of the copyrighted work. } \\
\text { § 109. Other limitations on exclusive rights of specific works. } \\
\text { Other limitations on exclusive rights of specific works or exemptions } \\
\text { of certain performances and displays may be prescribed by the } \\
\text { Attorney General in rules and regulations consistent with sections } 107 \\
\text { and } 108 \text { of this chapter. }\end{array}$ \\
\hline \multicolumn{2}{|l|}{ Indonesia } \\
\hline $\begin{array}{l}\text { Law of the } \\
\text { Republic of } \\
\text { Indonesia } \\
2014 \text { about } \\
\text { Copyright, } \\
\text { art } 15\end{array}$ & $\begin{array}{l}\text { (1) Unless otherwise agreed, the owners and/or holders of Creation } \\
\text { photography, paintings, drawings, works of architecture, sculpture, } \\
\text { or other artistic works the right to make announcement of a work in } \\
\text { a public exhibition or multiplication in a catalog produced for exhibition } \\
\text { purposes without the consent of the Creator. }\end{array}$ \\
\hline \multicolumn{2}{|l|}{ Palau } \\
\hline $\begin{array}{l}\text { Consolidated } \\
\text { Legislation Real } \\
\text { and Personal } \\
\text { Property Title } \\
39 \text { (Palau) } 39 \\
\text { PNC § } 821 .\end{array}$ & $\begin{array}{l}\text { Notwithstanding the provisions of section } 814 \text {, the public display } \\
\text { of originals or copies of works shall be permitted without the } \\
\text { authorization of the author or copyright owner, provided that the } \\
\text { display is made other than by means of a film, slide, television image } \\
\text { or otherwise on screen and provided further that the work has been } \\
\text { published or the original or the copy displayed has been sold, given } \\
\text { away, or otherwise transferred to another person by the author, } \\
\text { copyright owner, or their successors in title. }\end{array}$ \\
\hline
\end{tabular}




\begin{tabular}{|c|c|}
\hline Country Statute & Summary of freedom of panorama provision \\
\hline \multicolumn{2}{|l|}{ Philippines } \\
\hline $\begin{array}{l}\text { Intellectual } \\
\text { Property Code, } \\
\text { Republic Act } \\
\text { No. 8293, } \\
\text { s } 184.1\end{array}$ & $\begin{array}{l}\text { Notwithstanding the provisions of Chapter } \mathrm{V} \text {, the following acts shall } \\
\text { not constitute infringement of copyright ... } \\
\text { j. Public display of the original or a copy of the work not made by } \\
\text { means of a film, slide, television image or otherwise on screen or } \\
\text { by means of any other device or process: Provided, that either } \\
\text { the work has been published, or, that the original or the copy } \\
\text { displayed has been sold, given away or otherwise transferred to } \\
\text { another person by the author or his successor in title; } \\
\text { 184.2. The provisions of this section shall be interpreted in such a way } \\
\text { as to allow the work to be used in a manner which does not conflict } \\
\text { with the normal exploitation of the work and does not unreasonably } \\
\text { prejudice the right holder's legitimate interests. }\end{array}$ \\
\hline \multicolumn{2}{|c|}{ Papua New Guinea } \\
\hline $\begin{array}{l}\text { Copyright and } \\
\text { Neighbouring } \\
\text { Rights Act } \\
2000 \text {, s } 16\end{array}$ & $\begin{array}{l}\text { Notwithstanding the provisions of Section } 6(1)(\mathrm{g}) \text {, the public display } \\
\text { of originals or copies of works may be made without the authorisation } \\
\text { of the author, provided- } \\
\text { (a) that the display is made other than by means of a film, slide, } \\
\text { television image or otherwise on screen or by means of any other } \\
\text { device or process; and } \\
\text { (b) that the work has been published or the original or the copy } \\
\text { displayed has been sold, given away or otherwise transferred } \\
\text { to another person by the author or his successor in title. }\end{array}$ \\
\hline \multicolumn{2}{|l|}{ Samoa } \\
\hline $\begin{array}{l}\text { Copyright Act } \\
1998, \text { s } 15\end{array}$ & $\begin{array}{l}\text { Despite section 6(1)(f), the public display of originals or copies of } \\
\text { works shall be permitted without the authorisation of the author: } \\
\text { PROVIDED THAT- } \\
\text { (a) the display is made other than by means of a film, slide, } \\
\text { television image or otherwise on screen or by means of any other } \\
\text { device or process; and } \\
\text { (b) the work has been published or the original or the copy } \\
\text { displayed has been sold, given away or otherwise transferred } \\
\text { to another person by the author or his or her successor in title. } \\
\text { Section } 30 \\
\text { A person who, without the consent of the competent authority referred } \\
\text { to in section 29(4), uses a traditional cultural expression in a manner } \\
\text { not permitted by section } 29 \text { commits an offence in breach of a duty } \\
\text { under law, and is liable to the competent authority referred to in } \\
\text { section 29(4) for damages, injunctions and any other remedies as the } \\
\text { Court may deem fit. }\end{array}$ \\
\hline
\end{tabular}




\begin{tabular}{|c|c|}
\hline Country Statute & Summary of freedom of panorama provision \\
\hline \multicolumn{2}{|l|}{ Vanuatu } \\
\hline $\begin{array}{l}\text { Copyright and } \\
\text { Related Rights } \\
\text { Act 2000, s } 18\end{array}$ & $\begin{array}{l}\text { (1) A person may display in public the original or copies of a work if: } \\
\text { (a) the display is made other than by means of an audiovisual } \\
\text { work, slide, television image or otherwise on screen; and } \\
\text { (b) either: } \\
\text { (i) the work has been published; or } \\
\text { (ii) the original or the copy of the work displayed has been } \\
\text { sold, given away or otherwise transferred to another person } \\
\text { by the author or his or her successor in title. } \\
\text { (2) The display of the work in accordance with subsection (1) is not } \\
\text { an infringement of the copyright in the work. } \\
\text { (3) The display in public of the original or copies of a work by means } \\
\text { of an audiovisual work, slide, television image or otherwise on screen } \\
\text { is not an infringement of copyright in the work if its inclusion in such } \\
\text { is only incidental to the principal matters being represented. }\end{array}$ \\
\hline \multicolumn{2}{|c|}{ Commonwealth of the Northern Mariana Islands } \\
\hline $\begin{array}{l}\text { US legislation } \\
\text { applies, i.e. } \\
17 \text { USC } \\
\S 120(a)\end{array}$ & $\begin{array}{l}\text { The copyright in an architectural work that has been constructed } \\
\text { does not include the right to prevent the making, distributing, or } \\
\text { public display of pictures, paintings, photographs, or other pictorial } \\
\text { representations of the work, if the building in which the work is } \\
\text { embodied is located in or ordinarily visible from a public place. }\end{array}$ \\
\hline \multicolumn{2}{|l|}{ Guam } \\
\hline $\begin{array}{l}\text { US legislation } \\
\text { applies, i.e. } \\
17 \text { USC } \\
\S 120(a)\end{array}$ & $\begin{array}{l}\text { The copyright in an architectural work that has been constructed } \\
\text { does not include the right to prevent the making, distributing, or } \\
\text { public display of pictures, paintings, photographs, or other pictorial } \\
\text { representations of the work, if the building in which the work is } \\
\text { embodied is located in or ordinarily visible from a public place. }\end{array}$ \\
\hline \multicolumn{2}{|l|}{ Kiribati } \\
\hline $\begin{array}{l}\text { Laws of the } \\
\text { Republic of } \\
\text { Kiribati Revised } \\
\text { Edition } 1980, \\
\text { Chapter } 16 \\
\text { Copyright } \\
\end{array}$ & Minimalist legislation, no mention of public display etc. \\
\hline \multicolumn{2}{|l|}{ Tuvalu } \\
\hline $\begin{array}{l}\text { Copyright Act, } \\
1916\end{array}$ & Minimalist legislation, no mention of public display etc. \\
\hline
\end{tabular}

Source: Author's summary of legislation, as listed in table. 
This text is taken from Making Copyright Work for the Asian Pacific: Juxtaposing Harmonisation with Flexibility, edited by Susan Corbett and Jessica C Lai, published 2018 by ANU Press, The Australian National University, Canberra, Australia.

doi.org/10.22459/MCWAP.10.2018.08 